\title{
Protein Turnover in Tissues of the Rat Fetus following Maternal Starvation
}

\author{
JOHN D. JOHNSON, TRACY DUNHAM, BETTY J. SKIPPER, AND ROBERT B. LOFTFIELD \\ Departments of Pediatrics, Biochemistry and Family, Community and Emergency Medicine, University of New \\ Mexico School of Medicine, Albuquerque, New Mexico 87131
}

\begin{abstract}
The effects of maternal starvation upon protein turnover in various tissues of the fetal rat were determined. Protein synthesis was determined in fetal tissues by the intravenous injection of "massive" amounts of ${ }^{3} \mathrm{H}-$ phenylalanine into the maternal circulation, followed by measurements of tissue free and protein-bound phe specific radioactivity in fetal diaphragm, heart, liver, and brain. Rates of protein degradation in fetal tissues were assessed by subtracting protein accretion rates from protein synthesis. Fractional rates of protein synthesis were minimally affected by maternal starvation in diaphragm, heart, and brain. The major factor contributing to reduced fetal protein accretion in these fetal tissues during maternal starvation was enhanced protein breakdown. These findings differ from those previously reported in young adult rodents following fasting or malnutrition. (Pediatr Res 20: 12521257, 1986)
\end{abstract}

\section{Abbreviations}

$K_{s}$, fractional rate of protein synthesis

$K_{d}$, fractional rate of protein degradation

$\mathrm{K}_{\mathrm{g}}$, fractional rate of accretion of protein phe, phenylalanine

The rapid accretion of protein during growth of the fetus represents a balance between rates of protein synthesis and protein degradation. We have previously reported $(1,2)$ that rates of protein accretion in various tissues/or: as of the fetal rat at different stages of gestation result from alterations in both rates of protein synthesis and breakdown. Thus, in both diaphragm and heart, protein accretion during the most rapid phase of fetal growth is accomplished by higher rates of synthesis and lower rates of degradation when compared to a time of lesser growth (1).

It is, therefore, obvious that perturbations in fetal growth may result from alterations in either of these two components of protein turnover. Very few studies have addressed the mechanism(s) of altered fetal growth in these terms. We have determined protein turnover in vivo in various tissues of the fetal rat following total caloric restriction of maternal rats for a $72-\mathrm{h}$ period between 18-21 days gestation. Our results indicate that enhanced protein degradation is a critically important determinant of reduced rates of protein accretion in fetal diaphragm, heart, and brain following maternal starvation.

Received April 28, 1986; accepted July 16, 1986.

Reprints John D. Johnson, M.D., Department of Pediatrics, Surge Building, University of New Mexico, School of Medicine, Albuquerque, NM 87131.

Supported by National Institute of Child Health and Human Development Grants HD-15243 and HD-11327.

\section{METHODS}

Animals. Virgin Sprague-Dawley rats were mated at 100 days of age. Day 0 of gestation was defined as the day on which a pan plug was found (3). Throughout the mating period and the subsequent gestational period, animals were kept in a room controlled at $22 \pm 1^{\circ} \mathrm{C}$ with a 12-h on-off light cycle. Control animals were fed Wayne Lab Blox (Allied Mills, Chicago, IL, $24 \%$ protein) ad libitum throughout gestation. Animals in the experimental group were fed the same diet until day 18 of gestation, after which they were provided only with water.

Determination of protein synthesis. We utilized the method of Garlick et al. (4) to determine protein synthesis in vivo. With this technique, "massive" amounts of ${ }^{3} \mathrm{H}$-phe are injected into animals in an attempt to flood the precursor pools of protein synthesis. The precursor pool specific radioactivity is maintained relatively constant during the time period over which incorporation of ${ }^{3} \mathrm{H}$-phe into protein is measured. The applicability of this technique to measurement of fetal protein synthesis following ${ }^{3} \mathrm{H}$-phe administration to pregnant rats has been established by Goldspink and Kelly (5) and Lewis et al. (6).

In our experiments, protein synthesis was determined at day 21 gestation. Pregnant rats were injected with $150 \mu \mathrm{mol}$ phe containing $65 \mu \mathrm{Ci} \mathrm{L}-4-{ }^{3} \mathrm{H}$-phe (Amersham Corp., Arlington Heights, ILL, $25-26 \mathrm{Ci} / \mathrm{mmole})$ per $100 \mathrm{~g}$ body weight into an internal jugular vein with the animals under light ether anesthesia. Studies have shown no effect of ether anesthesia upon protein synthesis utilizing this technique (7). Pregnant rats were killed with an overdose of diethyl ether at 10,20, and $30 \mathrm{~min}$ following injection of phe; samples of maternal blood were obtained and fetuses were immediately submerged in ice-cold $0.9 \% \mathrm{NaCl}$. Fetal diaphragm, heart, brain, and liver were rapidly dissected and frozen in liquid nitrogen. Processing of blood and tissue samples to determine specific radioactivity of free and protein-bound phe was conducted precisely according to Garlick et al. (4). In brief, supernatants from perchloric acid-precipitated tissue homogenates were used for measurement of specific radioactivity of free tissue phe and $\mathrm{HCl}$ hydrolysates of washed perchloric acid precipitates of tissue samples were employed for determining specific radioactivity of protein-bound phe following its enzymatic conversion to $\beta$-phenethylamine. Fluorometric determination of $\beta$-phenethylamine utilized an excitation wavelength of $390 \mathrm{~nm}$ and an emission wavelength of $495 \mathrm{~nm}$ in a Farrand Ratio Fluorometer-2 (Farrand Optical Co., Inc., Valhalla, NY), equipped with a flow cell. Incubations and fluorescence determinations were performed in the dark. Radioactivity of extracted $\beta$-phenethylamine was determined in a scintillation spectrometer at $46-48 \%$ counting efficiency. Fractional rates of protein synthesis in fetal tissues were calculated from the equation, $K_{s}=\frac{S_{b}}{S_{a} \times t}$ where $S_{b}=$ specific radioactivity (dpm/nmole) of protein-bound phe, $S_{a}=$ specific radioactivity of free phe in tisuse, $t=$ time in days, and $K_{s}=$ fractional synthesis rate per 
day. Since $S_{a}$ did not change significantly over the $30 \mathrm{~min}$ of study, no correction for rate of change of $S_{a}$ over time was required (see "Results"). Additionally, since $S_{a}$ did not change significantly over $30 \mathrm{~min}$, all values for $S_{\mathrm{b}}$ from $10-30 \mathrm{~min}$ were utilized in the calculation of mean $\mathrm{K}_{\mathrm{s}}$. Comparisons of $\mathrm{K}_{\mathrm{s}}$ in control animals utilizing this technique versus a technique using continuous infusion of tracer amounts of ${ }^{14} \mathrm{C}$-tyrosine in to the maternal venous circulation were made $(1,2)$ (see "Results").

Determination of protein degradation. The protein balance equation for any tissue, organ or whole organism can be simply expressed in the equation $\mathrm{K}_{\mathrm{g}}=\mathrm{K}_{\mathrm{s}}-\mathrm{K}_{\mathrm{g}}$, where $\mathrm{K}_{\mathrm{g}}$ is the fractional rate of protein accretion per day, $\mathrm{K}_{\mathrm{s}}$ is the fraction of protein in the total pool that is synthesized per day, and $\mathrm{K}_{\mathrm{d}}$ is the fraction of protein in the total pool that is degraded per day. Rearrangement of this equation, solving for $\mathrm{K}_{d}$, gives the relationship $K_{d}=K_{s}-K_{g}$. We calculated $K_{d}$ by subtracting the $K_{g}$ from $\mathrm{K}_{\mathrm{s}}$. We directly determined $\mathrm{K}_{\mathrm{g}}$ by constructing growth curves for the protein content of the individual tissues from a separate group of fetuses for both control and fasting conditions. Data for protein accretion between days 19-22 gestation were analyzed by polynomial regression. Quadratic equations for protein accretion in fetal tissues from control and starved mothers are shown in "Results." Growth rates $(\mathrm{dP} / \mathrm{dt})$ were obtained from the derivatives of these equations, and fractional growth rates $\left(\mathrm{K}_{\mathrm{g}}\right)$ from the relation $\mathrm{K}_{\mathrm{g}}=\mathrm{dP} / \mathrm{dt} \div \mathrm{P}(\mathrm{t})$, where $\mathrm{P}(\mathrm{t})$ is the protein content at 21 days gestation.

Biochemical determinations. Protein content of fetal tissues was determined on tissue homogenates by the method of Lowry et al. (8) with bovine albumin as the standard. Extraction of RNA and DNA from tissue samples was performed as described by Munro and Fleck (9). RNA was determined on the basis of absorbance at $260 \mathrm{~nm}$ (9) and DNA by a diphenylamine procedure (10). Maternal and fetal plasma glucose concentration was measured by a glucose oxidase method (11); plasma insulin concentration was determined by a double-antibody radioimmunoassay (12) with rat insulin as the standard. For amino acid analysis, plasma samples were deproteinized with an equal volume of $5 \%$ sulfosalicyclic acid containing $400 \mu \mathrm{M}$ norleucine as an internal standard. Supernatants were stored at $-70^{\circ} \mathrm{C}$ until analyzed by ion-exchange liquid chromatography using the $\mathrm{Di}$ onex amino acid analyzer (Dionex Corporation, Sunnyvale, CA) with fluorometric detection using orthophthaldehyde. A standard mixture containing known quantities of amino acids was run prior to and after each group of plasma samples. Amino acid concentrations were calculated by integral area analysis.

\section{RESULTS}

Fetal growth curves. The effect of maternal starvation on fetal body weight is shown in Figure 1 . Decreased fetal body weight was evident by 48 hours of maternal starvation (day 20 gestation) and became accentuated with continued starvation. The effects of maternal starvation on fetal tissue protein content are illustrated in Figure 2. Rates of accretion of protein in diaphragm (and heart) are most significantly affected at 21-22 days gestation. Liver protein content is reduced in fetuses of starved mothers within $24 \mathrm{~h}$ of food deprivation, while brain protein content is reduced only between 72-96 h of maternal starvation (data not shown). Quadratic equations for changes in fetal tissue protein content from control and starved groups are expressed in Table 1. Greater variability in protein accretion rates are demonstrated for all tissues in fetuses from fasted mothers versus controls, as indicated by lesser $\mathrm{R}^{2}$ values for fetuses from starved mothers. Nonetheless, all growth equations are highly significant.

Protein synthesis. Tissue to plasma ratios of free ${ }^{3} \mathrm{H}$-phe specific radioactivity are close to unity for all fetal tissues in both control and fasted conditions (Table 2), illustrating the effectiveness of "flooding" the precursor pools with this technique. Fetal tissue-free phe specific radioactivity remains constant over a 30 min period in control and starved fetuses, while protein-bound

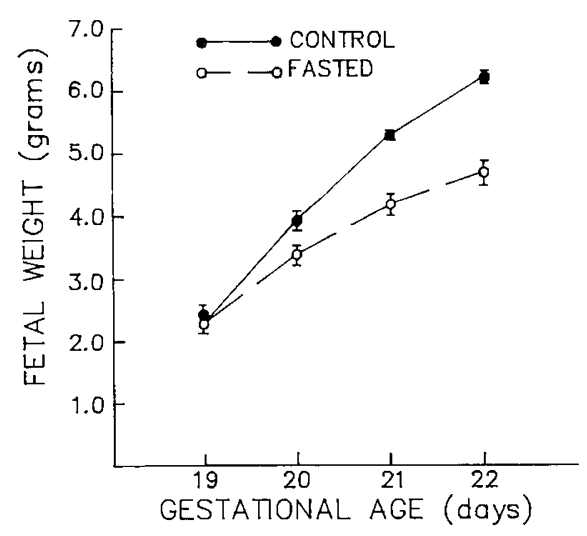

Fig. 1. Body weight of fetuses from control and starved mothers. Each point represents the mean body weight $( \pm \mathrm{SE})$ of from six to 10 litters. Each litter had nine to 16 fetuses. No differences in litter size were found between fetuses of control and starved mothers at any gestational age.

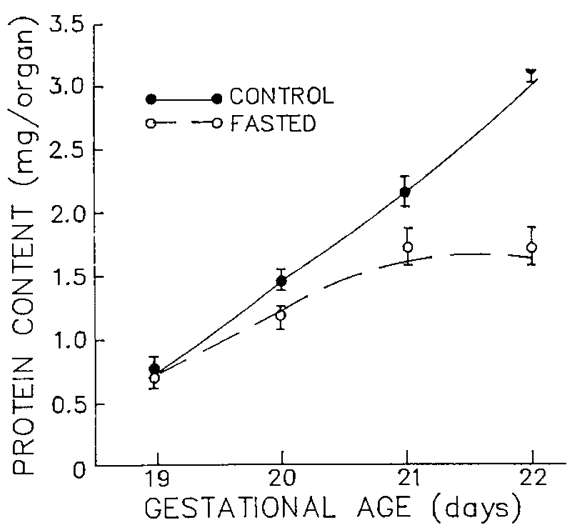

Fig. 2. Diaphragm protein content in fetuses from control and starved mothers. Each point represents the mean $( \pm \mathrm{SE})$ of from six to 10 litters (total of $80-140$ fetuses per time point). Each litter had nine to 16 fetuses. The protein content-gestational age curve for fetal heart is almost superimposable.

Table 1. Fetal organ protein accretion (quadratic equations)*

\begin{tabular}{ccc}
\hline Organ & Equation & $R^{2}$ value \\
\hline $\begin{array}{c}\text { Diaphragm } \\
\text { Control }\end{array}$ & $\mathrm{P}=13.48-1.93 \mathrm{GA}+0.066 \mathrm{GA}^{2}$ & 0.95 \\
Fasting & $\mathrm{P}=-65.99+6.28 \mathrm{GA}-0.146 \mathrm{GA}^{2}$ & 0.58 \\
& & \\
Heart & & 0.92 \\
Control & $\mathrm{P}=4.24-0.97 \mathrm{GA}+0.042 \mathrm{GA}^{2}$ & 0.49 \\
Fasting & $\mathrm{P}=-64.68+6.12 \mathrm{GA}-0.141 \mathrm{GA}^{2}$ & \\
Brain & & \\
Control & $\mathrm{P}=54.54-7.26 \mathrm{GA}+0.253 \mathrm{GA}^{2}$ & 0.85 \\
Fasting & $\mathrm{P}=-277.7+26.3 \mathrm{GA}-0.592 \mathrm{GA}^{2}$ & 0.57 \\
& & \\
Liver & & \\
Control & $\mathrm{P}=-400.8+35.31 \mathrm{GA}-0.689 \mathrm{GA}^{2}$ & 0.83 \\
Fasting & $\mathrm{P}=-328.4+32.46 \mathrm{GA}-0.749 \mathrm{GA}^{2}$ & 0.32 \\
\hline
\end{tabular}

$* \mathrm{P}$, protein content (mg/organ); GA, gestational age (days).

specific radioactivity increases in a linear fashion (Fig. 3). Comparisons of $K_{s}$ values in control fetal tissues determined by continuous infusion of tracer quantities of ${ }^{14} \mathrm{C}$-tyrosine $(1,2)$ versus the rapid infusion of "massive" quantities of ${ }^{3} \mathrm{H}$-phe are 
Table 2. Tissue to plasma ratios of ${ }^{3} H$-phe specific radioactivity*

\begin{tabular}{ccccc}
\hline & Diaphragm & Heart & Liver & Brain \\
\hline Control & $0.995(0.070)$ & $0.976(0.065)$ & $0.936(0.059)$ & $1.016(0.072)$ \\
Fasted & $0.933(0.050)$ & $0.915(0.033)$ & $0.861(0.032)$ & $0.900(0.040)$ \\
\hline
\end{tabular}

$*$ Values represent means \pm SE in parentheses for 11-16 litters of fetal rats. No significant differences for these ratios between control and fasted fetuses were detected for any of the tissues using the $t$ test for independent samples.
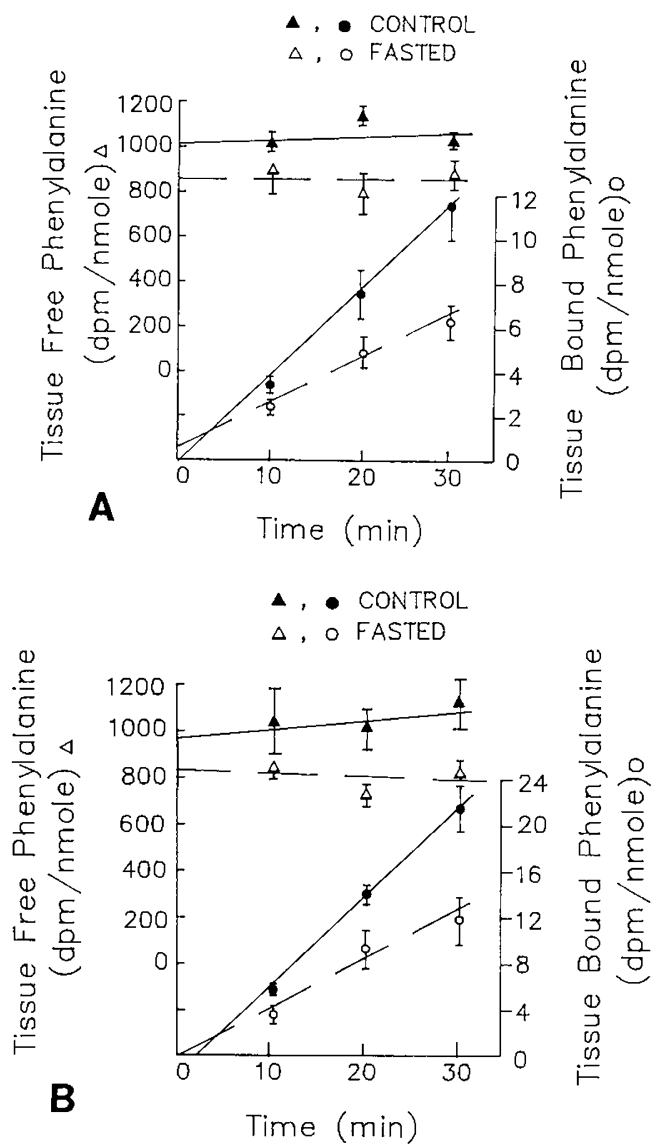

Fig. 3. Tissue-free and protein-bound specific radioactivity of ${ }^{3} \mathrm{H}$-phe in fetal liver $(A)$ and diaphragm $(B)$ at 21 days gestation. Each point represents the mean $\pm \mathrm{SE}$ of three to six litters at each time. Tissues from all fetuses of a litter were pooled for analysis. Slopes of the values for tissue free ${ }^{3} \mathrm{H}$-phe specific radioactivity (SRA) were not significantly different from zero for these tissues (as well as for brain and heart), while slopes of the values for tissue bound SRA were all significantly different from zero, with $p$ values of $<0.001$. Correlation coefficients for the slopes of tissue bound SRA were 0.94 and 0.85 for normal liver and diaphragm, respectively; and 0.70 and 0.76 for liver and diaphragm from fetuses of starved mothers.

Table 3. Comparison of "continuous infusion" and "massive injection" techniques for determination of protein synthesis in fetal tissues- $K_{s}($ per day)*

\begin{tabular}{lcc}
\hline Tissue & $\begin{array}{c}\text { Continuous } \\
\text { Infusion }\end{array}$ & $\begin{array}{c}\text { Massive } \\
\text { Injection }\end{array}$ \\
\hline Brain & $0.47 \pm 0.029$ & $0.42 \pm 0.023$ \\
Heart & $0.61 \pm 0.036$ & $0.56 \pm 0.045$ \\
Liver & $0.81 \pm 0.079$ & $0.94 \pm 0.071$ \\
Diaphragm & $0.54 \pm 0.031$ & $0.49 \pm 0.035$ \\
\hline
\end{tabular}

* Values represent means \pm SE for 21-day control fetal tissues. Those determined by the continuous infusion technique were previously reported $(1,2)$ except for liver (Johnson JD, unpublished observations).
Table 4. Rate constants for protein synthesis, accretion, and degradation in fetal tissues*

\begin{tabular}{ccccc}
\hline Tissue & $\begin{array}{c}\mathrm{K}_{\mathrm{s}} \\
\left(\text { days }^{-1}\right)\end{array}$ & & $\begin{array}{c}\mathrm{K}_{\mathrm{g}} \\
\left(\text { days }^{-1}\right)\end{array}$ & $\begin{array}{c}\mathrm{K}_{\mathrm{d}} \\
\left(\text { days }^{-1}\right)\end{array}$ \\
\hline $\begin{array}{c}\text { Diaphragm } \\
\text { Control }\end{array}$ & $0.487(0.035)$ & 0.396 & 0.091 \\
Fasting & $0.395(0.029)$ & $p=0.052$ & 0.095 & 0.300 \\
$\begin{array}{c}\text { Heart } \\
\text { Control }\end{array}$ & $0.560(0.045)$ & & 0.337 & 0.223 \\
Fasting & $0.548(0.019)$ & & 0.119 & 0.429 \\
Brain & & & & \\
Control & $0.419(0.023)$ & & 0.246 & 0.173 \\
Fasting & $0.467(0.024)$ & & 0.106 & 0.361 \\
Liver & & & & \\
Control & $0.936(0.071)$ & & 0.173 & 0.763 \\
$\quad$ Fasting & $0.761(0.070)$ & $p=0.10$ & 0.044 & 0.717 \\
\hline
\end{tabular}

* Values for the fractional rate constant $\mathrm{K}_{\mathrm{s}}$ represent means of 10-16 litters with SEs in parentheses. $p$ values were calculated using the twotailed $t$ test for independent samples. $\mathrm{K}_{\mathrm{g}}$ and $\mathrm{K}_{\mathrm{d}}$ were defined and calculated as described in "Methods." All values were determined at 21 days gestation.

Table 5. Absolute rates of protein synthesis and protein degradation in control and starved fetuses at 21 days gestation

\begin{tabular}{lcccc}
\hline & Diaphragm & Heart & Brain & Liver \\
\hline Protein synthesis* & & & & \\
$\quad$ Control & 1.05 & 1.37 & 5.67 & 33.2 \\
$\quad$ Fasted & 0.68 & 1.09 & 6.69 & 18.3 \\
& & & & \\
Protein degradation* & & & & \\
$\quad$ Control & 0.20 & 0.54 & 2.34 & 28.9 \\
$\quad$ Fasted & 0.52 & 0.98 & 5.17 & 17.2 \\
\hline
\end{tabular}

* Synthesis or degradation in $\mathrm{mg}$ per tissue per day.

shown in Table 3. Very similar $\mathrm{K}_{\mathrm{s}}$ values are obtained with the two techniques. The largest difference is for liver $\left(\mathrm{K}_{\mathrm{s}}\right.$ greater using massive injection versus continuous infusion). This difference is explainable when one considers that short-term labelling of liver protein with the massive injection method involves the detection of both stable and secreted protein (e.g. albumin), whereas the continuous infusion technique involves the labelling mainly of stable liver protein (13).

$\mathrm{K}_{\mathrm{s}}$ values for fetal tissues of control and starved fetuses are shown in Table $4 . K_{s}$ is somewhat reduced in diaphragm and liver in fetuses of fasted mothers versus controls, although the differences do not reach statistical significance. Absolute rates of protein synthesis (Table 5) are reduced in diaphragm, heart, and liver in fetuses of starved mothers, but not in the brain. Table 6 shows that fractional protein synthesis per unit RNA or DNA is 
not affected by maternal starvation. RNA "concentration," as reflected by the RNA/protein ratio, is significantly decreased in fetal liver and brain of fetuses from starved mothers.

Protein degradation. Calculated $\mathrm{K}_{\mathrm{d}}$ values in fetuses of fasted mothers are increased in diaphragm, heart, and brain versus controls, while $\mathrm{K}_{d}$ is unchanged in liver following maternal starvation for $72 \mathrm{~h}$ (Table 4). Absolute rates of protein breakdown are also accelerated in fetal diaphragm, heart and brain in association with maternal starvation (Table 5).

Plasma glucose and insulin. Figure 4 shows that plasma glucose and insulin were decreased in starved mothers and fetuses versus controls.

Plasma amino acids. As seen in Table 7, maternal plasma concentrations of taurine, methionine, isoleucine, tyrosine, and phe and the sum of all three branched chain amino acids increased significantly following $72 \mathrm{~h}$ starvation. Conversely, most amino acids decreased in fetal plasma following maternal starvation. These decreases were statistically significant for glutamic acid, citrulline, alanine, valine, the sum of the branched chain group, and the total of all 19 amino acids quantitated. Fetal amino acid concentrations were approximately 2-fold higher than maternal values in control animals and, for the most part,

Table 6. RNA and DNA activities in tissues of the fetal rat at 21 days gestation*

\begin{tabular}{lcccc}
\hline Tissue & $\begin{array}{c}\mathrm{K}_{\mathrm{s}} \\
\left(\text { days }^{-1}\right)\end{array}$ & $\begin{array}{c}\text { RNA } \\
\text { activity }\end{array}$ & $\begin{array}{c}\text { DNA } \\
\text { activity }\end{array}$ & $\begin{array}{c}\text { RNA/protein } \\
\left(\times 10^{3}\right)\end{array}$ \\
\hline Heart & & & & \\
$\quad$ Control & 0.560 & 12.04 & 6.66 & 47.1 \\
Fasted & 0.548 & 11.45 & 7.51 & 49.4 \\
& & & & \\
Diaphragm & & & & \\
$\quad$ Control & 0.487 & 11.83 & 7.40 & 40.6 \\
Fasted & 0.395 & 9.95 & 5.96 & 41.6 \\
& & & & \\
Liver & & & & \\
Control & 0.936 & 10.39 & 5.28 & 91.6 \\
Fasted & 0.761 & 10.35 & 7.14 & $74.9 \dagger$ \\
Brain & & & & \\
Control & 0.419 & 7.75 & 3.43 & 53.7 \\
Fasted & 0.467 & 10.60 & 4.93 & $44.3 \dagger$ \\
\hline
\end{tabular}

${ }^{*}$ RNA activity $=\mathrm{K}_{\mathrm{s}} \cdot$ protein/RNA (g protein/g RNA/day); DNA activity $=\mathrm{K}_{\mathrm{s}} \cdot$ protein $/ \mathrm{DNA}$ (g protein $/ \mathrm{g}$ DNA/day).

$\dagger p<0.05$ control versus fasting.

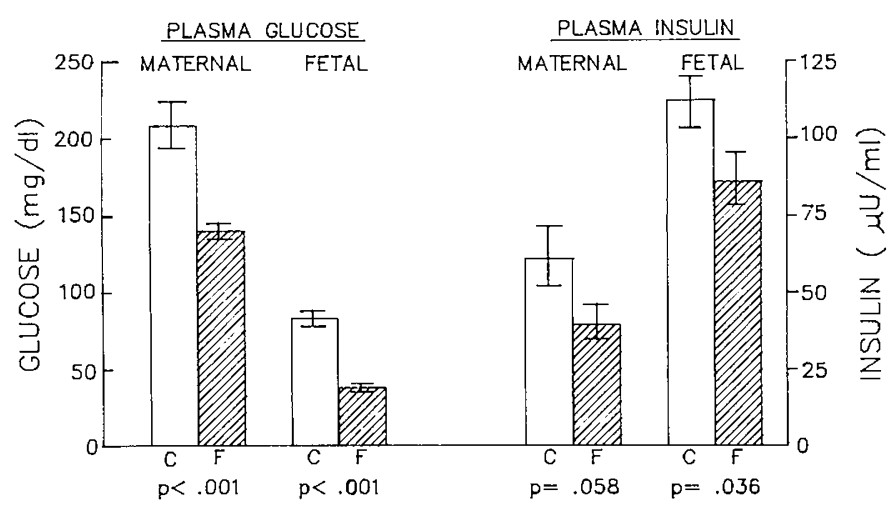

Fig. 4. Plasma glucose and insulin in mothers and fetuses under control and fasting conditions at 21 days gestation. Values represent means $\pm \mathrm{SE}$ of from nine to 11 individual pregnant rats at 21 days gestation for both glucose and insulin and from eight to 11 litters of fetuses (blood pooled for each litter). Statistical significance was determined using the Student's $t$ test for independent samples. corresponded closely with those previously reported by Girard $e t$ al. (14) for full-term fetal rats.

\section{DISCUSSION}

The present studies confirm the utility of the "massive" injection of radioactive phenylalanine into the maternal circulation for measurement of fetal protein synthesis in vivo. With this technique, fetal plasma and tissue free specific radioactivity remain constant for at least $30 \mathrm{~min}$ following injection of the isotope into the maternal circulation. Fractional rates of protein synthesis in tissues of control fetuses are comparable to those previously determined using a different technique $(1,2)$. This method for determining rates of protein synthesis in fetal tissues has the advantages that 1) time of the experimental procedure is brief, and 2) there is little question regarding the specific radioactivity of the precursor pool for protein synthesis. Effects of such large amounts of a single amino acid on protein synthesis have not been found to be significant $(4,13)$.

The conclusion to be drawn from our findings is that increased rates of protein breakdown are of major importance in the determination of reduced fetal growth rates in diaphragm, heart, and brain associated with maternal starvation in the rat. Only one previous study of which we are aware has addressed protein turnover in fetal tissues following maternal starvation. In that study (15), absolute rates of protein synthesis in organs of the fetal sheep following $48 \mathrm{~h}$ of maternal starvation were unchanged in heart and skeletal muscle, but markedly decreased in both liver and brain.

Our findings regarding protein turnover in fetal animals following maternal starvation differ significantly from those of other investigators studying young adult rats. Several investigators have studied protein turnover in various tissues of the young adult rat and reported that starvation or low protein diets result in a marked decrease in $\mathrm{K}_{\mathrm{s}}(13,16,17)$. It would appear that several tissues of the rat fetus are relatively resistant to the effects of starvation on protein synthesis.

No clear-cut explanation for the different response to starvation between fetal and postnatal rats is evident. Protein synthesis per unit RNA (translational efficiency of ribosomes) is not altered significantly in fetuses of starved mothers (Table 6), but is reduced when young adult rats are starved or subjected to protein deprivation (17-19). Studies of the regulation of RNA turnover during perinatal development are warranted to dissect these mechanisms.

The mechanism for accentuated protein degradation in several fetal tissues associated with maternal starvation is not clear. At least two separate pathways for protein degradation have been described in mammalian tissues: one is the lysosomal pathway, believed to be involved in the degradation of long-lived proteins during both basal conditions and nutritional deprivation (2022). The second, a cytosolic ATP-dependent process, is thought to degrade abnormal and other short-lived proteins selectively $(21,23)$. Insulin is believed to be important in retarding protein degradation in a number of mammalian tissues, and appears to act by controlling the lysosomal proteolytic system either directly and/or by influencing access of autophagic vacuoles to lysosomes (24). The reduced concentration of insulin in plasma of fetuses from starved mothers in this study could have contributed to the enhanced protein breakdown observed in several tissues, but the reduction in insulin concentration was not marked. Other factors known to influence protein breakdown in mammalian tissues, such as plasma amino acids (22) and somatomedin (25), might also be important regulatory factors influencing fetal protein degradation during maternal starvation.

Maternal starvation resulted in increases in plasma concentrations of the branched chain amino acids and methionine, although to a much lesser degree than previously reported for starved, nonpregnant rats (18). Fetal plasma concentrations of 
Table 7. Maternal and fetal plasma amino acids in control and fasting animals*

\begin{tabular}{|c|c|c|c|c|}
\hline \multirow[b]{2}{*}{ Amino acid } & \multicolumn{2}{|c|}{ Maternal $(\mu \mathrm{M})$} & \multicolumn{2}{|c|}{ Fetal $(\mu \mathrm{M})$} \\
\hline & Control & Fasting & Control & Fasting \\
\hline Taurine & $166(5)$ & $427(16) \dagger$ & $342(61)$ & $346(21)$ \\
\hline Aspartic acid & $45(6)$ & $35(4)$ & $70(9)$ & $51(4)$ \\
\hline Threonine & $196(13)$ & $172(24)$ & $381(43)$ & $280(33)$ \\
\hline Serine & $218(14)$ & $178(21)$ & $439(42)$ & $331(24)$ \\
\hline Glutamine & $297(27)$ & $288(27)$ & $535(92)$ & $474(35)$ \\
\hline Glutamic acid & $337(10)$ & $285(17)$ & $510(21)$ & $356(19) \dagger$ \\
\hline Citrulline & $37(4)$ & $19(3) \dagger$ & $38(4)$ & $20(4) \dagger$ \\
\hline Glycine & $133(23)$ & $202(33)$ & $379(15)$ & $340(23)$ \\
\hline Alanine & $541(33)$ & $358(61)$ & $737(4)$ & $559(18) \dagger$ \\
\hline Valine & $99(3)$ & $123(9)$ & $363(25)$ & $240(16) \dagger$ \\
\hline Methionine & $28(1)$ & $43(4) \dagger$ & $105(11)$ & $99(9)$ \\
\hline Isoleucine & $83(6)$ & $112(4) \dagger$ & $213(21)$ & $180(11)$ \\
\hline Leucine & $91(3)$ & $106(6)$ & $293(22)$ & $230(12)$ \\
\hline Tyrosine & $34(1)$ & $54(5) \dagger$ & $196(17)$ & $199(5)$ \\
\hline Phe & $40(1)$ & $61(6) \dagger$ & $160(1)$ & $195(13) \dagger$ \\
\hline Histidine & $48(4)$ & $68(11)$ & $137(15)$ & $101(21)$ \\
\hline Lysine & $502(51)$ & $491(61)$ & $835(148)$ & $945(143)$ \\
\hline Tryptophan & $20(2)$ & $19(2)$ & $76(8)$ & $70(2)$ \\
\hline Arginine & $90(10)$ & $62(15)$ & $247(22)$ & $186(6)$ \\
\hline Totals & $3004(44)$ & $3103(217)$ & $6054(237)$ & $5200(165) \dagger$ \\
\hline Branched chain & $273(12)$ & $341(17) \dagger$ & $869(67)$ & $649(14) \dagger$ \\
\hline
\end{tabular}

* Values represent means with SEs in parentheses.

$\dagger$ Significant difference $(p \leq 0.05)$ between control and fasting with 2-tailed $t$ test for independent samples. All determinations were performed at day 21 gestation.

branched-chain amino acids, glutamic acid, citrulline, and alanine decreased during maternal fasting. These results contrast with those of Lemons and Schreiner (26) for the ovine fetus, in which maternal fasting resulted in an increase in the concentration of a majority of amino acids in fetal blood. Since amino acid uptake by the mammalian fetus is dependent on uterine blood flow (27), and since fetal amino acid uptake in the ovine fetus does not change during maternal fasting (26), the increase in fetal amino acids seen as a consequence of maternal fasting in the sheep may reflect augmented tissue proteolysis. On the other hand, Rosso (28) has reported decreased placental blood flow and reduced transfer of ${ }^{14} \mathrm{C}$ - $\alpha$-amino isobutyric acid from mother to fetus when pregnant rats were fed a low-protein diet. Thus, the decreased concentration of various amino acids observed in plasma of fetuses from starved mothers in our experiments is consistent with reduced placental transfer.

Although the branched-chain amino acids clearly stimulate protein synthesis and inhibit degradation in muscle tissue incubated in vitro and in perfused liver, their effects on protein turnover in vivo remain controversial (29). Studies in vitro indicate that leucine inhibits the breakdown of long-lived, but not short-lived proteins both in muscle and liver $(30,31)$ and, therefore, presumably acts on the lysosomal proteolytic system. The reduced concentrations of plasma amino acids in rat fetuses from starved mothers did not result in decreaesd fractional rates of protein synthesis, but could have contributed to the accelerated rate of protein degradation observed in striated muscle and brain.

In growing myotube cultures, leucine does not retard the degradation of long-lived proteins (30), and in growing fibroblasts, both short-lived and long-lived proteins appear to be degraded by a nonlysosomal process (32). Whether the enhanced protein degradation in fetal striated muscle following maternal starvation in our studies results from activation of lysosomal or cytosolic mechanisms of proteolysis is unclear. Further studies are necessary to differentiate these possibilities.

Acknowledgments. The authors thank Robert E. Greenberg for reviewing the manuscript, Karen Olson for preparation of the manuscript, and Jim Standefer for determining plasma insulin concentrations.

\section{REFERENCES}

1. Johnson JD, Wetmore DL 1984 Protein turnover in heart and diaphragm of rat fetus. Am J Physiol 247:E781-E785

2. Johnson JD 1985 Protein turnover in brain of the rat fetus. $\mathbf{J}$ Neurochem 44:260-264

3. Szabo KT, Free SM, Birkhead HA, Gay PE 1969 Predictability of pregnancy from various signs of mating in mice and rats. Lab Anim 19:822-825

4. Garlick PJ, McNurlan MA, Preedy VR 1980 A rapid and convenient technique for measuring the rate of protein synthesis in tissues by injection of $\left[{ }^{3} \mathrm{H}\right]$ phenylalanine. Biochem J 192:719-723

5. Goldspink DF, Kelly FJ 1984 Protein turnover and growth in the whole body liver and kidney of the rat from the foetus to senility. Biochem J 217:507516

6. Lewis SEM, Kelly FJ, Goldspink DF 1984 Pre- and post-natal growth and protein turnover in smooth muscle, heart and slow-and fast-twitch skeletal muscles of the rat. Biochem $\mathbf{J} 217: 517-526$

7. Sampson DA. Masor M, Jansen GR 1984 Protein synthesis in rat tissues during lactation. No effect of diethyl ether anaesthesia. Biochem J 224:681-683

8. Lowry OH, Rosebrough NJ, Farr AL, Randall RJ 1951 Protein measurement with the folin phenol reagent. J Biol Chem 193:265-275

9. Munro HN, Fleck A 1969 Analysis of tissues and body fluid for nitrogenous constituents. In: Munro HN (ed) Mammalian Protein Metabolism, vol 3. New York. Academic Press, pp 423-525

10. Giles KW, Myers A 1965 An improved diphenylamine procedure for the estimation of deoxyribonucleic acid. Nature 206:93

11. Huggett ASC, Nixon DA 1957 Use of glucose oxidase, peroxidase and odianisidine in determination of blood and urinary glucose. Lancet 2:368370

12. Hales CM, Randle PH 1963 Immunoassay of insulin with insulin-antibody precipitate. Biochem J 88:137-146

13. McNurlan MA, Tomkins AM, Garlick PJ 1979 The effect of starvation on the rate of protein synthesis in rat liver and small intestine. Biochem J 178:373379

14. Girard JR, Guillet I, Marty J, Assan R, Marliss EB 1976 Effects of exogenous hormones and glucose on plasma levels and hepatic metabolism of amino acids in the fetus and in the newborn rat. Diabetologia 12:327-337

15. Krishnamurti CR, Schaefer AL 1984 Effect of maternal starvation on tyrosine metabolism and protein synthesis in fetal sheep. Growth 48:391-403

16. Millward DJ, Garlick PH, Stewart RJC, Nnanyelugo DO, Waterlow JC 1975 Skeletal muscle growth and protein turnover. Biochem J 150:235-243

17. Millward DJ, Waterlow JC 1978 Effect of nutrition on protein turnover in skeletal muscle. Fed Proc 37:2283-2290

18. Millward DJ, Garlick PH, Nnanyelugo DO, Waterlow JC 1976 The relative 
importance of muscle protein synthesis and breakdown in the regulation of muscle mass. Biochem J 156:185-188

19. McNurlan MA. Garlick PH 1981 Protein synthesis in liver and small intestine in protein deprivation and diabetes. Am J Physiol 241:E238-E245

20. Goldberg A. St. John AC 1976 Intracellular protein degradation in mammalian and bacterial cells. Ann Rev Biochem 45:747-803

21. Hershko A, Ciechanover A 1982 Mechanisms of intracellular protein breakdown. Ann Rev Biochem 51:335-364

22. Mortimore GE, Poso AR 1984 Lysosomal pathways in hepatic protein degradation: regulatory role of amino acids. Fed Proc 43:1289-1294

23. Ciechanover A, Finley D, Varshavsky A 1984 The ubiquitin-mediated proteolytic pathway and mechanisms of energy-dependent intracellular protein degradation. J Cell Biochem 24:27-53

24. Long WM. Chua BH. Munger BL. Morgan HE 1984 Effects of insulin on cardiac lysosomes and protein degradation. Fed Proc 43:1295-1300

25. Florini JR, Ewton DZ, Ewinger-Hodges MJ, Falen SL, Law RL, Regan JF Vertel BM 1984 Stimulation and inhibition of myoblast differentiation by hormones. In Vitro 20:942-958

26. Lemons JA, Schreiner RL 1983 Amino acid metabolism in the ovine fetus. Am J Physiol 244:E459-E466

27. Morriss FH Jr, Adcock EW III, Paxson CL Jr, Greeley WJ Jr 1979 Uterine uptake of amino acids throughout gestation in the unstressed ewe. Am J Obstet Gynecol 135:601-608

28. Rosso P 1981 Nutrition and maternal-fetal exchange. Am J Clin Nutr 34:744755

29. Smith R, Elia M 1983 Branched-chain amino acids in catabolic states. Proc Nutr Soc 42:473-487

30. Vandenburgh H, Kaufman S 1980 Protein degradation in embryonic skeletal muscle. J Biol Chem 255:5826-5832

31. Mortimore G 1982 Mechanisms of cellular protein catabolism. Nutr Rev 40:112

32. Gronostajski RM, Pardee AB, Goldberg AL 1985 The ATP dependence of the degradation of short- and long-lived proteins in growing fibroblasts. J Biol Chem 260:3344-3349 